\title{
INTERPHASE INCISION ON THE LIMIT WELDING OF ORTHOTROPIC PLATE WITH ELLIPTICAL HOLE AND CLOSED ELASTIC RIB
}

\author{
Andriy Syasky'; Oleg Dejneka ${ }^{2}$ \\ ${ }^{1}$ Rivne State University of Humanities, Rivne, Ukraine \\ ${ }^{2}$ National University of Water and Environmental Engineering, Rivne, Ukraine
}

\begin{abstract}
Summary. In a generalized plane stressed state, a mixed contact problem for an infinite orthotropic plate with an elliptical hole, whose contour is amplified by a closed elastic rib, is considered in the presence of a symmetric interfacial section of a small width at the boundary of their weld, the shores of which in the process of deformation are not in contact. By simulating the reinforcing rib with a curvilinear rod of a stable rectangular cross-section, and a welding seam - a elastic line of constant rigidity on tension (compression), a system of singular integral differential equations was constructed to determine the contact forces on the surfaces of the separation of the plate materials, the welding seam and the reinforcing rib, as well as the internal forces factors in the seam and the rib. In order to find the initial parameters in a statically uncertain closed rib, the conditions for unambiguous displacement of the points of its axis and the angles of rotation of the cross sections are used. The structure of the desired functions at the ends of the plot of the junction of the plate and the rib is established. The approximate solution of the problem was constructed by the method of mechanical quadratures and collocation, which investigated the effect of the stiffness of the weld seam on the distribution of the components of the stressed state along the contour of the hole in the plate in the welding joint and the reinforcing rib.

Key words: orthotropic plate, elastic rib, welding seam, interphase incision, contact forces, internal force
\end{abstract} factors.

Problem statement. Thin-walled structures in the form of thin plates with curvilinear holes, the contours of which are reinforced by closed elastic ribs, find wide application in various branches of engineering practice. Reinforcing ribs, typically making up a relatively small fraction of the total weight of the structure, significantly affect its strength, stiffness and stability.

The intensive development of modern engineering and construction has led to extensive use of piece-uniform plates made of composite materials.

Analysis of known research results. The solution of the problem of determining the stressed-deformed state of a plate with a hole, the contour of which is reinforced by a closed elastic rib, depends significantly on the choice of a mathematical model of the rib and the method of its combination with the plate.

The most common is currently the model of curved rod of constant crosssection [1-3], and the method of its communication is equivalent to ideal mechanical contact [2]. Using this approach, the works [1-3] consider a number of problems about the contact of the closed elastic rib with the contour of the elliptical hole in the infinite orthotropic plastic, which is in the conditions of the generalized flat stress state, when combined with the guaranteed tension or welding method.

During manufacture or operation of a plate with a closed stiffening rib, interfacial defects (cracks or zero-width cuts) may occur on the facet of mating different materials, which may cause further interfacial breakage. 
Simulating the welding joint with the ideal mechanical contact between the plate and the reinforcing rib, $[4,5]$ has built approximate solutions to the problems for the endless orthotropic plate with circular and elliptical holes in the presence of a zero-width interfacial cut, the banks of which do not contact during deformation. For the case of a real weld, such tasks were not considered.

Setting objectives. Consider an infinite orthotropic plate thick $2 h$, with an elliptical hole bounded by a smooth cylindrical surface. Its median plane is assigned to Cartesian $(x, y)$ and polar $(r, \delta)$ coordinate systems with a pole $O$ in the center of the hole. Polar axis coincides with axis $O x$ and axis of symmetry of hole and defines one of main directions of orthotropy of plate material. The line of intersection of the midplance plane with the surface of the hole is indicated through $H$ and we call the contour of the hole with the radius of curvature $\rho$.

Assume that in the region $\left[-\alpha_{0}^{*}, \alpha_{0}^{*}\right]\left(\alpha_{0}^{*}-\right.$ polar angle) the contour $H$ is reinforced by a closed elastic rib in the form of a cylindrical shell with thickness $2 \eta_{1}$ and height $2 h_{1}$. Plate and rib are connected symmetrically relative to mid plane by welding method. The welding joint is considered part of a non-stop open cylindrical shell with thickness $b_{0}$ and height $2 h$.

Plate structure is considered in conditions of generalized flat stress state caused by uniformly distributed forces $p$ and $q$ acting at infinity in directions of coordinate axes.

The purpose of the work is to determine the components of the stressed state on the contour $H$ in the plate, reinforcement rib and weld.

Main equations of the problem. We conditionally divide the three-component structure into separate elements (endless orthotropic plate with elliptical hole, welding seam, reinforcing rib), replacing the action of one body with another by unknown contact forces.

The infinite orthotropic plate is in equilibrium under the action of the load on infinity and normal and tangential contact forces $T_{\rho}, S_{\rho \lambda}$, which are transmitted to the contour $H$ from the side of the weld.

Let the shape of the elliptical hole in the plate be determined by the function [6]

$$
z=x+i y=\omega(\zeta)=R_{0}\left(\zeta+\frac{\varepsilon}{\zeta}\right)
$$

a conformal mapping of the appearance $S^{-}$of the unit circle $\gamma$ in the area $\zeta=\tilde{\rho} e^{i \lambda}$ to the area occupied by the middle plane of the plate. Here $R_{0}=\frac{a+b}{2}=1$ - characteristic size of the hole; $\varepsilon=\frac{a-b}{a+b}-$ eccentricity of the ellipse; $a=1+\varepsilon, b=1-\varepsilon-\operatorname{semi}$-axes of the ellipse; $(\tilde{\rho}, \lambda)-$ polar coordinates of points in the plane $\zeta ; i=\sqrt{-1}$.

The deformations of the elliptical hole $H$ contour in the plate at the specified load are determined from the ratios [5]

$$
\begin{aligned}
& \varepsilon_{\lambda}=\frac{1}{2 E_{x} h\left(\alpha^{2}+\beta^{2}\right)}\left\{C(\lambda) T_{\rho}(\lambda)-\frac{1}{\pi} \int_{-\alpha_{0}}^{\alpha_{0}}\left[\Phi_{1}(\lambda, t) T_{\rho}(t)+\Phi_{2}(\lambda, t) S_{\rho \lambda}(t)\right] d t+\alpha \tilde{\varepsilon}_{\lambda}^{0}+\beta \tilde{V}^{0}\right\} \\
& V=\frac{1}{2 E_{x} h\left(\alpha^{2}+\beta^{2}\right)}\left\{C(\lambda) S_{\rho \lambda}(\lambda)+\frac{1}{\pi} \int_{-\alpha_{0}}^{\alpha_{0}}\left[\Phi_{3}(\lambda, t) S_{\rho \lambda}(t)+\Phi_{4}(\lambda, t) T_{\rho}(t)\right] d t+\alpha \tilde{V}^{0}-\beta \tilde{\varepsilon}_{\lambda}^{0}\right\},
\end{aligned}
$$


were

$$
\begin{gathered}
\Phi_{1}(\lambda, t)=H_{1}(\lambda, t)-G_{1}(\lambda, t) \operatorname{ctg} \frac{\lambda-t}{2} ; \Phi_{2}(\lambda, t)=-G_{1}(\lambda, t)-H_{1}(\lambda, t) \operatorname{ctg} \frac{\lambda-t}{2} ; \\
\Phi_{3}(\lambda, t)=H_{2}(\lambda, t)-G_{2}(\lambda, t) \operatorname{ctg} \frac{\lambda-t}{2} ; \Phi_{4}(\lambda, t)=G_{2}(\lambda, t)+H_{2}(\lambda, t) \operatorname{ctg} \frac{\lambda-t}{2} ; \\
C(\lambda)=\left(\beta_{1} \beta_{2}-v_{x}\right)\left(\alpha^{2}+\beta^{2}\right) ; \alpha+i \beta=\omega^{\prime}(\sigma) ; \sigma=e^{i \lambda} ;
\end{gathered}
$$

$\varepsilon_{\lambda}, V$ - relative elongation of contour $H$ and the angle of rotation of the to it; $E_{x}, v_{x}$ - Young's modulus and Poisson's ratio of plate material in direction of axis $O x ; \beta_{1}, \beta_{2}$ - roots of characteristic equation [6]; $\left[-\alpha_{0}, \alpha_{0}\right]$ - image of section at display (1). The remaining designations are as in [5].

If the contact forces become known, the ring forces $T_{\lambda}$ on $H$ can be determined according to the formula given in [5].

Welding seam, as a part of open nonmotent shell, in common middle plane of plate and ribs will be identified with elastic line of constant stiffness for tension (compression) $E_{0} F_{0}$ of ( $E_{0}$ - Young 's modulus of weld material), which in section of communication coincides with contour $H$. Its deformation is performed by contact forces $\Delta T=T_{\rho}-T_{\rho}^{(1)}, \Delta S=S_{\rho \lambda}-S_{\rho \lambda}^{(1)}$, transmitted to it from plate $\left(T_{\rho}, S_{\rho \lambda}\right)$ and reinforcing rib $\left(T_{\rho}^{(1)}, S_{\rho \lambda}^{(1)}\right)$.

Stress-deformed condition of weld joint is determined by axial longitudinal force $N^{(0)}$ and relative elongation $\varepsilon_{\lambda}^{(0)}$, which are connected to each other by the Hooke's law [7]

$$
N^{(0)}(\lambda)=E_{0} F_{0} \varepsilon_{\lambda}^{(0)}(\lambda)
$$

Differential equilibria of the seam element

$$
N^{(0)}(\lambda)=\rho \Delta T(\lambda) ; \quad \Delta S(\lambda)=\frac{-d N^{(0)}(\lambda)}{\left|\omega^{\prime}(\sigma)\right| d \lambda}
$$

or

$$
T_{\rho}^{(1)}(\lambda)=T_{\rho}(\lambda)-\frac{N^{(0)}(\lambda)}{\rho} ; \quad S_{\rho \lambda}^{(1)}(\lambda)=S_{\rho \lambda}(\lambda)+\frac{d N^{(0)}(\lambda)}{\left|\omega^{\prime}(\sigma)\right| d \lambda}
$$

allow the conditions of equilibrium of the seam as a rigid whole

$$
\int_{-\alpha_{0}}^{\alpha_{0}}(\Delta T(\lambda)+i \Delta S(\lambda)) \sigma \omega^{\prime}(\sigma) d \lambda=0
$$

transform to look 


$$
N^{(0)}\left(-\alpha_{0}\right)=N^{(0)}\left(\alpha_{0}\right)=0 \text {. }
$$

Reinforcing rib is modeled by closed curvilinear rod (ring) of constant rectangular cross section, is in equilibrium under action of contact forces $T_{\rho}^{(1)}, S_{\rho \lambda}^{(1)}$ transmitted in its outer side surface from welding seam.

The components of the stress state of such a rod will be represented as

$$
N_{1}=-N_{0} \cos \theta+\tilde{N} ; \quad Q_{1}=-N_{0} \sin \theta+\tilde{Q} ; \quad L_{b}^{(1)}=L_{b}+\left[x-x_{0}-\eta_{1}(1+\cos \theta)\right] N_{0}+\tilde{L}_{b},
$$

where $N_{1}, Q_{1}, L_{b}^{(1)}$ - longitudinal and transverse forces and bending moment arising in cross sections of rod and related to its axis; $N_{0}, Q_{0}=0, L_{b}^{0}-$ similar values in conventional cross section of rod by plane; $\theta=-\pi ; \widetilde{N}, \widetilde{Q}, \widetilde{L}_{b}$ - corresponding components (6) caused by contact forces; $\theta$ - the angle of the normal at the point $(x, y)$ of the contour $H$ to the axis $O x$; $x_{0}=x(-\pi) ; \tilde{N}\left(-\alpha_{0}\right)=\widetilde{Q}\left(-\alpha_{0}\right)=\widetilde{L}_{b}\left(-\alpha_{0}\right)=0 ; e^{i \theta}=\sigma \omega^{\prime}(\sigma) /\left|\omega^{\prime}(\sigma)\right|$.

Stress-deformed state of open rib will describe the main equations of one-dimensional theory of curvilinear rods based on the hypothesis of flat sections [5]:

- differential equations of rod element equilibrium

$$
\begin{gathered}
T_{\rho}^{(1)}(\lambda)=T_{\rho}(\lambda)-\frac{N^{(0)}(\lambda)}{\rho}=\frac{\widetilde{N}(\lambda)}{\rho}-\frac{d \widetilde{Q}(\lambda)}{\left|\omega^{\prime}(\sigma)\right| d \lambda} ; \tilde{L}_{b}(\lambda)-\eta_{1} \tilde{N}(\lambda)-\int_{-\alpha_{0}}^{\lambda} \tilde{Q}(\lambda)\left|\omega^{\prime}(\sigma)\right| d \lambda=0 ; \\
S_{\rho \lambda}^{(1)}(\lambda)=S_{\rho \lambda}(\lambda)+\frac{d N^{(0)}(\lambda)}{\left|\omega^{\prime}(\sigma)\right| d \lambda}=-\frac{\widetilde{Q}(\lambda)}{\rho}-\frac{d \widetilde{N}(\lambda)}{\left|\omega^{\prime}(\sigma)\right| d \lambda} ;
\end{gathered}
$$

weld

- physical dependencies for the outer longitudinal fiber of the rod, which contacts the

$$
\varepsilon_{\lambda}^{(c)}=\frac{1}{E_{1} F_{1}}\left[N_{1}(\lambda)+\frac{\eta_{1}+\eta_{c}}{\rho} \cdot \frac{\rho-\eta_{1}}{\omega_{0}} L_{b}^{(1)}(\lambda)\right] ; \quad \frac{d \theta_{b}}{d \theta}=\frac{1}{E_{1} F_{1}}\left[N_{1}(\lambda)+\frac{\rho-\eta_{1}}{\omega_{0}} L_{b}^{(1)}(\lambda)\right] .
$$

Here the symbol is put: $\varepsilon_{\lambda}^{(c)}, \theta_{b}$ - the relative elongation of the fiber and the angle of rotation of the normal to it; $E_{1} F_{1}-$ the tensile (compression) stiffness of the rod; $\eta_{c}$ - the distance from the axis of the rod to the neutral for pure bending of the longitudinal fiber; $\omega_{0}=\left(\rho-\eta_{1}\right) \eta_{c}$; $E_{1}, v_{1}$ - You1ng 's modulus and Poisson ratio of rod material;

- equilibrium conditions of the reinforcing rib as a rigid whole

$$
\int_{-\alpha_{0}}^{\alpha_{0}}\left(T_{\rho}^{(1)}(\lambda)+i S_{\rho \lambda}^{(1)}(\lambda)\right) e^{i \lambda} \omega^{\prime}(\sigma) d \lambda=0 ; \quad \widetilde{L}_{b}\left(\alpha_{0}\right)-\eta_{1} \widetilde{N}\left(\alpha_{0}\right)-\int_{-\alpha_{0}}^{\alpha_{0}} \widetilde{Q}(\lambda)\left|\omega^{\prime}(\sigma)\right| d \lambda=0,
$$

which with (6) can be converted to a view

$$
\tilde{N}\left( \pm \alpha_{0}\right)=\widetilde{Q}\left( \pm \alpha_{0}\right)=\widetilde{L}_{b}\left( \pm \alpha_{0}\right)=0
$$


Initial parameters $N_{0}, L_{b}^{0}$ are determined from conditions of uniqueness of edge crosssection rotation angle and offsets of points of its axis [5]

$$
\begin{gathered}
\int_{-\alpha_{0}}^{\alpha_{0}}\left[\frac{\tilde{N}(\lambda)}{\rho}+\left(1-\frac{\eta_{1}}{\rho}\right) \frac{\widetilde{L}_{b}(\lambda)}{\omega_{0}}\right]\left|\omega^{\prime}(\sigma)\right| d \lambda+\frac{L_{b}^{0}}{\omega_{0}} \int_{-\pi}^{\pi}\left(1-\frac{\eta_{1}}{\rho}\right)\left|\omega^{\prime}(\sigma)\right| d \lambda+ \\
+\frac{N_{0}}{\omega_{0}} \int_{-\pi}^{\pi}\left(1-\frac{\eta_{1}}{\rho}\right)\left[x-\left(\eta_{1}+\eta_{c}\right) \cos \theta-x_{0}-\eta_{1}\right]\left|\omega^{\prime}(\sigma)\right| d \lambda=0 \\
\int_{-\alpha_{0}}^{\alpha_{0}}\left[(\rho \cos \theta-x) \frac{\tilde{N}(\lambda)}{\rho}+\left(1-\frac{\eta_{1}}{\rho}\right)\left(\left(\eta_{1}+\eta_{c}\right) \cos \theta-x\right) \frac{\widetilde{L}_{b}(\lambda)}{\omega_{0}}\right]\left|\omega^{\prime}(\sigma)\right| d \lambda+ \\
+\frac{L_{b}^{0}}{\omega_{0}} \int_{-\pi}^{\pi}\left(1-\frac{\eta_{1}}{\rho}\right)\left(\left(\eta_{1}+\eta_{c}\right) \cos \theta-x\right)\left|\omega^{\prime}(\sigma)\right| d \lambda+N_{0} \int_{-\pi}^{\pi}\left[(x-\rho \cos \theta) \frac{\cos \theta}{\rho}+\right. \\
\left.+\left(1-\frac{\eta_{1}}{\rho}\right) \frac{\left(\left(\eta_{1}+\eta_{c}\right) \cos \theta-x\right)\left(x-x_{0}-\eta_{1}(\cos \theta+1)\right)}{\omega_{0}}\right]\left|\omega^{\prime}(\sigma)\right| d \lambda=0
\end{gathered}
$$

Mathematical problem model. The boundary conditions of the task are formulated in the form of conditions of seam deformation of the plate, weld and reinforcing rib

$$
\varepsilon_{\lambda}(\lambda)=\varepsilon_{\lambda}^{(0)}(\lambda)=\varepsilon_{\lambda}^{(c)}(\lambda) ; \quad V(\lambda)=\theta_{b}(\lambda), \quad \lambda \in\left[-\alpha_{0} ; \alpha\right]
$$

Substituting (2), (3), (8) into edge conditions (12), after certain transformations, we obtain a system of singular integral equations with Hilbert nuclei to determine contact forces $T_{\lambda}, S_{\rho \lambda}$ and functions $N^{(0)}, \tilde{N}, \tilde{Q}, \tilde{L}_{b}$,

$$
\begin{gathered}
\frac{E_{1} F_{1}}{2 E_{x} h\left(\alpha^{2}+\beta^{2}\right)}\left\{C(\lambda) T_{\rho}(\lambda)-\frac{1}{\pi} \int_{-\alpha_{0}}^{\alpha}\left[\Phi_{1}(\lambda, t) T_{\rho}(t)+\Phi_{2}(\lambda, t) S_{\rho \lambda}(t)\right] d t+\alpha \widetilde{\varepsilon}_{\lambda}^{0}+\beta \widetilde{V}^{0}\right\}= \\
=-N_{0} \cos \theta+\widetilde{N}+\frac{\eta_{1}+\eta_{c}}{\rho} \cdot \frac{\rho-\eta_{1}}{\omega_{0}}\left(L_{b}^{0}+\left(x-x_{0}-\eta_{1}(1+\cos \theta)\right) N_{0}+\widetilde{L}_{b}\right) \\
\left.\frac{E_{1} F_{1}}{2 E_{x} h\left(\alpha^{2}+\beta^{2}\right)}\left\{C(\lambda) S_{\rho \lambda}(\lambda)+\frac{1}{\pi} \int_{-\alpha_{0}}^{\alpha}\left[\Phi_{3}(\lambda, t) S_{\rho \lambda}(t)+\Phi_{4}(\lambda, t) T_{\rho}(t)\right)\right] d t+\alpha \widetilde{V}^{0}-\beta \widetilde{\varepsilon}_{\lambda}^{0}\right\}= \\
=\int_{0}^{\lambda}\left[-N_{0} \cos \theta+\widetilde{N}+\frac{\rho-\eta_{1}}{\omega_{0}}\left(L_{b}^{0}+\left(x-x_{0}-\eta_{1}(1+\cos \theta)\right) N_{0}+\widetilde{L}_{b}\right)\right]\left|\omega^{\prime}(\sigma)\right| d \lambda ; \\
N^{(0)}(\lambda)=\frac{E_{0} F_{0}}{E_{1} F_{1}}\left\{\frac{\eta_{1}+\eta_{c}}{\eta_{c} \rho}\left(L_{b}^{0}+\widetilde{L}_{b}\right)+\widetilde{N}+\left[\frac{\left(x-x_{0}-\eta_{1}(1+\cos \theta)\right)\left(\eta_{1}+\eta_{c}\right)}{\eta_{c} \rho}-\cos \theta\right] N_{0}\right\}, \\
\lambda \in\left[-\alpha_{0} ; \alpha_{0}\right] .
\end{gathered}
$$


This system is supplemented by differential equilibrium equations of rib (7) and conditions (11).

The relations (7), (11), (13) form a complete system of equations for determining functions $T_{\lambda}, S_{\rho \lambda}, N^{(0)}, \tilde{N}, \tilde{Q}, \tilde{L}_{b}$, constant $N_{0}, L_{b}^{0}$ and form a mathematical model of the problem.

If the desired functions and steel become known, the ring forces on the contour $H$ in the plate can be determined by formula [5], the internal forces and moments in the amplification rib from the ratios (6), and the values $T_{\rho}^{(1)}, S_{\rho \lambda}^{(1)}$ is based on the dependencies (4).

Normal stresses in the outer and inner longitudinal fibers of the rib are found according to Hooke 's law in its one-dimensional form [5]

$$
\sigma^{(1)}=\frac{1}{F_{1}}\left[N_{1}+\frac{\eta_{1}+\eta_{c}}{\rho} \cdot \frac{\rho-\eta_{1}}{\omega_{0}} L_{b}^{(1)}\right] ; \quad \sigma^{(2)}=\frac{1}{F_{1}}\left[N_{1}+\frac{\eta_{c}-\eta_{1}}{\rho-2 \eta_{1}} \cdot \frac{\rho-\eta_{1}}{\omega_{0}} L_{b}^{(1)}\right] .
$$

Putting in (7), (11), (13), we get a mathematical model of the task for the case when the welding seam is replaced by an ideal mechanical contact between the plate and the reinforcing rib [5].

Approximate solution of the problem. The exact solution of the system (7), (11), (13) cannot be found. For its approximate solution it is necessary to find structure of sought functions at ends of section of plate and reinforcing rib communication.

On the basis of relations (5), (10) it can be concluded that functions $N^{(0)}, \tilde{N}, \tilde{Q}$ and $\tilde{L}_{b}$ are limited and continuous at the interval $\left[-\alpha_{0} ; \alpha_{0}\right]$ and at its ends are zero.

Contact forces $T_{\rho}, S_{\rho \lambda}$ at the ends $\lambda= \pm \alpha_{0}$ have root feature with local oscillation [5, 8]. Ignoring its influence, the approximate solution of the problem can be built by the method of mechanical quadratures and collocation. Quadrature formulas of this method for singular and regular integrals are given in $[7,8]$.

Analysis of numerical results. For orthotropic plate with elliptical $(\varepsilon=0.2)$ hole and elastic rib with parameters:

$$
h_{1} / h=4 / 3 ; \quad \eta_{1} / R_{0}=0.1 ; \quad \sqrt{E_{x} E_{y}} / E_{1}=0.5 ; \quad \alpha_{0}=2 \pi / 3
$$

the effect of the relative stiffness of the weld on the distribution of the stress state components in the weld plate and the reinforcement rib has been studied.

Results of numerical calculation of maximum values $T_{\rho}, S_{\rho \lambda}, T_{\lambda}$ on the $H$ plate contour; $\sigma^{(1)} F_{1}, \quad \sigma^{(2)} F_{1}$ in the reinforcement rib; $\sigma^{(0)} F_{0}$ in the weld at $b_{0}=0.2 \eta_{1}$, $p=0, q=1$ are given in Table 1 . The values of the angle $\lambda$ for which the corresponding values were determined are given in parentheses. 
Table 1

Maximum values of the components of the stress state in the plate, reinforcing ribs and seam

\begin{tabular}{|c|c|c|c|c|c|c|c|c|}
\hline $\begin{array}{c}\text { Material } \\
\text { of the } \\
\text { plate }\end{array}$ & $\frac{E_{0}}{E_{1}}$ & $T_{\rho}(0)$ & $S_{\rho \lambda}(\pi / 6)$ & $T_{\lambda}(0)$ & $T_{\lambda}(\pi)$ & $\sigma^{(1)} F_{1}(0)$ & $\sigma^{(2)} F_{1}(\pi / 3)$ & $\sigma^{(0)} F_{0}(0)$ \\
\hline \multirow{3}{*}{$\begin{array}{l}\text { graphite- } \\
\text { epoxide }\end{array}$} & 1 & 4.4365 & 0.0717 & 0.3718 & 1.7033 & 3.8399 & 2.8945 & 0.5760 \\
\hline & 5 & 5.1698 & 0.2445 & 0.2182 & 1.7180 & 3.0353 & 2.8147 & 2.2765 \\
\hline & 10 & 5.7347 & 0.3460 & 0.0943 & 1.7298 & 2.4277 & 2.7483 & 3.6415 \\
\hline \multirow{3}{*}{$\begin{array}{l}\text { epoxy- } \\
\text { glass }\end{array}$} & 1 & 1.8824 & 0.6767 & 0.8992 & 1.8468 & 1.5546 & 0.8274 & 0.2332 \\
\hline & 5 & 2.2265 & 0.8420 & 0.7731 & 1.8536 & 1.2698 & 0.8038 & 0.9524 \\
\hline & 10 & 2.5108 & 0.9650 & 0.6683 & 1.8593 & 1.0415 & 0.7801 & 1.5622 \\
\hline \multirow{3}{*}{$\begin{array}{l}\text { isotropic } \\
\text { material }\end{array}$} & 1 & 1.0932 & 0.7305 & 1.1932 & 2.0378 & 1.0067 & 0.3785 & 0.1510 \\
\hline & 5 & 1.3118 & 0.8835 & 1.0819 & 2.0430 & 0.8263 & 0.3681 & 0.6141 \\
\hline & 10 & 1.4947 & 1.0044 & 0.9902 & 2.0475 & 0.6801 & 0.3566 & 1.0201 \\
\hline \multirow{3}{*}{$\begin{array}{l}\text { epoxide- } \\
\text { glass }\end{array}$} & 1 & 0.7103 & 0.7189 & 1.5453 & 2.8288 & 0.7767 & 0.2236 & 0.1153 \\
\hline & 5 & 0.8527 & 0.8445 & 1.3495 & 2.8340 & 0.6326 & 0.2164 & 0.4744 \\
\hline & 10 & 0.9706 & 0.9625 & 1.2305 & 2.8386 & 0.5173 & 0.2079 & 0.7760 \\
\hline \multirow{3}{*}{$\begin{array}{l}\text { epoxide- } \\
\text { graphite }\end{array}$} & 1 & 0.2771 & 0.6235 & 3.0245 & 6.3854 & 0.5172 & 0.1036 & 0.0776 \\
\hline & 5 & 0.3259 & 0.7134 & 2.6167 & 6.3916 & 0.4081 & 0.0964 & 0.3060 \\
\hline & 10 & 0.3641 & 0.7826 & 2.3055 & 6.3974 & 0.3252 & 0.0883 & 0.4878 \\
\hline
\end{tabular}

Calculations were made for orthotropic material with physical and mechanical characteristics of: graphite-epoxide $\left(\beta_{1}=6.9992 ; \quad \beta_{2}=0.7144 ; \quad v_{x}=0.25 ; \quad E_{x} / E_{y}=25\right)$; glass-epoxide $\left(\beta_{1}=2.2712 ; \quad \beta_{2}=0.7626 ; \quad v_{x}=0.25 ; \quad E_{x} / E_{y}=3\right)$; isotropic material $\left(\beta_{1}=\beta_{2}=1 ; \quad v_{x}=0.3 ; \quad E_{x} / E_{y}=1\right) ;$ epoxide-glass $\left(\beta_{1}=0.44 ; \quad \beta_{2}=1.31 ; \quad v_{x}=0.083 ;\right.$ $\left.E_{x} / E_{y}=1 / 3\right)$; epoxide-graphite $\left(\beta_{1}=0.143 ; \quad \beta_{2}=1.401 ; \quad v_{x}=0.01 ; \quad E_{x} / E_{y}=1 / 25\right)$.

Conclusions. For all considered orthotropic materials maximum forces on the contour of the plate hole grow at magnification $E_{0} / E_{1}$, and ring forces on the reinforcement section are dwindling. Annular forces at the interfacial section are practically independent of the weld stiffness. Increasing the ratio $E_{0} / E_{1}$ results in a significant reduction of the maximum normal stresses in the external longitudinal fibers of the reinforcing rib and has practically no effect on the distribution of similar stresses in the internal fibers. The longitudinal force in the weld is related to the value $E_{0} / E_{1}$ of the substantially linear relationship.

\section{References}

1. Martyinovich T. L., Yurinets V. E. Kontaktnyie vzaimodeystviya plastin s uprugimi elementami. Lvov: Vyisshaya shkola, 1984. $160 \mathrm{p}$.

2. Sheremetev M. P. Plastinki s podkreplennyim kraem. Lvov: Izdatelstvo Lvovskogo universiteta, 1960. 258 p.

3. Bozhydarnik V. V., Andreikiv O. Ye., Sulym H. T. Mekhanika ruinuvannia, mitsnisti dovhovichnist neperervno armovanykh kompozytsii. Vol. 2. Matematychni metody v zadachakh neperervno armovanykh kompozytiv. Lutsk: Nadstyrya, 2007. 410 p.

4. Siaskyi A. O., Shevtsova N. V., Dejneka O. Yu. Mizhfaznyi rozriz v ortotropnii plastyntsi z pidsylenym kruhovym konturom. Visnyk Khmelnytskoho natsionalnoho universytetu. 2018. № 5 (265). P. 176-181.

5. Siaskyi A. O., Shevtsova N. V., Dejneka O. Yu. Mizhfaznyi rozriz v ortotropnii plastyntsi z eliptychnym konturom, pidsylenym pruzhnym rebrom. Visnyk Khmelnytskoho natsionalnoho universytetu. 2019. № 1 (269). P. 31-39.

6. Lehnitskiy S. G. Anizotropnyie plastinki. Moskva: Gostehizdat, 1957. 464 p.

7. Syaskiy A. A., Syaskiy V. A. Napryazhennoe sostoyanie kusochno-odnorodnoy plastinki s uprugim vklyucheniem. Prikladnaya mehanika. 1983. Vol. 19. № 5. P. 94-99. https://doi.org/10.1111/j.14751305.1983.tb00457.x 
8. Syaskiy A. A. Uprugoe ravnovesie plastinki s chastichno podkreplennyim krivolineynyim otverstiem. Prikladnaya matematika i mehanika. 1986. Vol. 50. № 2. P. 247-254.

\title{
Список використаної літератури
}

1. Мартынович Т. Л., Юринец В. Е. Контактные взаимодействия пластин с упругими элементами. Львов: Высшая школа, 1984. 160 с.

2. Шереметьев М. П. Пластинки с подкрепленным краем. Львов: Издательство Львовского университета, 1960. $258 \mathrm{c}$.

3. Божидарнік В. В., Андрейків О. Є., Сулим Г. Т. Механіка руйнування, міцність і довговічність неперервно армованих композицій. Т. 2. Математичні методи в задачах неперервно армованих композитів. Луцьк: Надстир'я, 2007. 410 с.

4. Сяський А. О., Шевцова Н. В., Дейнека О. Ю. Міжфазний розріз в ортотропній пластинці 3 підсиленим круговим контуром. Вісник Хмельницького національного університету. 2018. № 5 (265). С. 176-181.

5. Сяський А. О., Шевцова Н. В., Дейнека О. Ю. Міжфазний розріз в ортотропній пластинці 3 еліптичним контуром, підсиленим замкненим пружним ребром. Вісник Хмельницького національного університету. 2019. № 1 (269). С. 31-39.

6. Лехницкий С. Г. Анизотропные пластинки. Москва: Гостехиздат, 1957. 464 с.

7. Сяський А. А., Сяський В. А. Напряженное состояние кусочно-однородной пластинки с упругим включением. Прикладная механика. 1983. Т. 19. № 5. С. 94-99. https://doi.org/10.1111/j.14751305.1983.tb00457.x

8. Сяський А. А. Упругое равновесие пластинки с частично подкрепленным криволинейным отверстием. Прикладная математика и механика. 1986. Т. 50. № 2. С. 247-254.

\section{УДК 539.3}

\section{МІЖФАЗНИЙ РОЗРІЗ НА МЕЖІ ЗВАРЮВАННЯ ОРТОТРОПНОЇ ПЛАСТИНКИ 3 ЕЛІПТИЧНИМ ОТВОРОМ І ЗАМКНЕНОГО ПРУЖНОГО РЕБРА}

\author{
Андрій Сяський'; Олег Дейнека ${ }^{2}$ \\ ${ }^{1}$ Рівненський державний гуманітарний університет, Рівне, Україна \\ ${ }^{2}$ Національний університет водного господарства та \\ природокористування, Рівне, Украӥна
}

\begin{abstract}
Резюме. В умовах узагальненого плоского напруженого стану, створеного рівномірно розподіленими зусиллями, які діють на нескінченності в напрямках координатних осей, розглянуто мішану контактну задачу для нескінченної ортотропної пластинки з еліптичним отвором, контур якого підсилений замкненим пружним ребром, за наявності на межі їх зварювання симетричного міжфазного розрізу малої ширини, береги якого в прочесі деформації не контактують. Моделюючи підсилювальне ребро замкненим криволінійним стрижнем сталого прямокутного поперечного перерізу, а зварювальний шов - пружною лінією сталої жорсткості на розтяг (стиск), побудовано систему сингулярних інтегрально-диферениіальних рівнянь з ядрами Гільберта для визначення контактних зусиль на поверхнях поділу матеріалів пластинки, зварювального шва і підсилювального ребра, а також внутрішніх силових факторів у шві та ребрі. При цьому напружено-деформований стан розімкненого ребра описано основними рівняннями одновимірної теорії криволінійних стрижснів, побудованими з урахуванням гіпотези плоских перерізів, а зварювального шва - рівняннями деформації пружної лінії. Для знаходження початкових параметрів у статично невизначеному замкненому ребрі використано умови однозначності зміщень точок його осі та кутів повороту поперечних перерізів. Встановлено структуру шуканих функиій на кінцях ділянки сполучення пластинки й ребра. Наближений розв'язок задачі побудовано методом механічних квадратур і колокачії, яким досліджено вплив ортотропії матеріалу пластинки та відносної жорсткості зварювального шва на розподіл компонент напруженого стану по контуру отвору в пластиниі, зварювальному шві й підсилювальному ребрі.
\end{abstract}

Ключові слова: ортотропна пластика, пружне ребро, зварювальний шов, міжфазний розріз, контактні зусилля, внутрішні силові фактори. 